\title{
Faith Manifest: Spiritual and Mindfulness Tourism in Chiang Mai, Thailand
}

\author{
Jaeyeon Choe * and Michael O' Regan \\ Faculty of Management, Bournemouth University, Poole BH12 5BB, UK; moregan@bournemouth.ac.uk \\ * Correspondence: jchoe@bournemouth.ac.uk
}

Received: 14 January 2020; Accepted: 2 April 2020; Published: 9 April 2020

\begin{abstract}
From books to movies, the media is now flush with spiritual and wellness tourist-related images, films, and fiction (which are primarily produced in the West) about Southeast Asia. Combined with the positive effects of spiritual practices, greater numbers of tourists are travelling to Southeast Asia for mindfulness, yoga, and other spiritual pursuits. Influenced by popular mass media coverage, such as Hollywood movies and literary bestsellers like Eat Pray Love (2006) and tourism imaginaries about particular peoples and places, spiritual tourists are visiting Southeast Asia in increasing numbers. They travel to learn about and practice mindfulness, so as to recharge their batteries, achieve spiritual fulfillment, enhance their spiritual well-being, and find a true self. However, there is a notable lack of scholarly work around the nature and outcomes of spiritual tourism in the region. Owing to its Buddhist temples, cultural heritage, religious history, infrastructure, and perceived safety, Chiang Mai in Thailand, in particular, has become a major spiritual tourism destination. Based on participant observation including informal conversations, and 10 semi-structured interviews in Chiang Mai during two summers in 2016 and 2018, our research explored why Western tourists travel to Chiang Mai to engage in mindfulness practices regardless of their religious affiliation. We explored their faith in their spiritual practice in Chiang Mai. Rather than the faith implied in religion, this faith refers to trust or confidence in something. Interestingly, none of the informants identified themselves as Buddhist even though many had practiced Buddhist mindfulness for years. They had faith that mindfulness would resolve problems, such as depression and anxiety, following life events such as divorces, deaths in family, drug abuse, or at least help free them from worries. They noted that mindfulness practices were a constructive means of dealing with negative life events. This study found that the informants sought to embed mindfulness and other spiritual practices into the fabric of their everyday life. Their faith in mindfulness led them to a destination where Buddhist heritage, history, and culture are concentrated but also consumed. Whilst discussing the preliminary findings through a critical lens, the research recommends future research pathways.
\end{abstract}

Keywords: faith; mindfulness; spiritual tourism; Chiang Mai; Thailand; tourism imaginaries; Southeast Asia

\section{Introduction}

Millions of people around the world travel to distant places, which they consider spiritual, in a quest to experience 'something' beyond their ordinary existence (Tilson 2005). Spiritual tourism has become a global phenomenon and a major socioeconomic influence on local communities and nation-states in developing regions (Tilson 2005). The United Nations World Tourism Organization (UNWTO 2013) states that "the cultural exchange and dialogue evoked by spiritual tourism are the very cornerstones of mutual understanding, tolerance and respect, the fundamental building blocks of sustainability" (p. 2), while Cheer et al. (2017) noted the positive potential of spiritual tourism, especially in countries of the Global South. 
Spiritual tourism is not a new phenomenon as spiritual tourism has been a popular form of tourism since the 1960s (Norman 2011). Hippies in the 1960s (MacCannell 2013, pp. 171-72) and later 'drifter' tourists (Cohen 1979) explored perceived exotic, mysterious and non-Western destinations (Palmer 1994) such as Nepal and India. Influenced by travel narratives such as Jack Kerouac's On the Road (Kerouac 1957), the Beatles's visit to Rishikesh, India, in 1968 (Ireland and Gemie 2015; Regan 1967; Reck 1985), tens of thousands of North Americans and northwestern Europeans traveled to Morocco, Afghanistan, India, Nepal, and other points east on the Hippy Trail (Ireland and Gemie 2015). While some were searching for an alternative to the 9-to- 5 conventions of Western society at the time, others sought spiritual enlightenment. Others saw their travel as a political statement against consumerism and materialism, and some just wanted to see the East (Ireland and Gemie 2015).

Over the past three decades, empirical research outcomes about the benefits of mindfulness (e.g., Kabat-Zinn 2015) and media coverage have fueled interest in spiritual tourism within Western countries to outbound travel destinations in Asia. Neuroscience and psychological studies, for example, have found that mindfulness helps with sleep, stress, anxiety, emotion regulation, loneliness, depression, compassion, relationships, cognitive function, attention, blood pressure, immune response, and pain management, etc. (Landau 2011; Marchant 2011; Norman and Pokorny 2017; Schocker 2014). Among several Hollywood films featuring the spiritual journey to Asia, Eat Pray Love (Gilbert 2006) attracted and continues to attract millions of tourists to India and Bali, Indonesia to find their 'true self' (Brenhouse 2010). Western yoga and mindfulness centers in Southeast Asia have flourished, with particular destinations, once explored as off-the-beaten-track locations by backpackers, now globally known, heavily commercialized and trafficked tourist destinations ( $\mathrm{O}^{\prime}$ Connor and Kim 2014). These destinations have also been developed as tourist destinations, not merely because of mass media, but also as a result of local tourism authorities and tour companies catering for the increasing 'faith' in spiritual, wellness, yoga, and health tourism.

Spiritual tourism is often described by Western scholars (e.g., Norman and Pokorny 2017) as an active choice by individuals to address a problem in their lives, and thereby acting as an important well-being intervention. Through spiritual travel and practice, individuals seek to understand and learn strategies to help "resolve problems in their reflective assessments, everyday experience, and personal outlook on life" (Norman and Pokorny 2017, p. 205). The tourist search for 'authenticity' in ancient and significant religious heritage sites associated with spirituality in South and Southeast Asia is influenced by the media and 'Orientalism' (Said 1978; see also King 2017). Thus, destinations such as Varanasi (India), Luang Prabang (Laos), Bagan (Myanmar), Chiang Mai (Thailand), and Ubud (Indonesia) have seen increasing numbers of 'spiritual' tourists. Norman (2011) found that tourists to Rishikesh (India), for example, practice their spiritual activities back home before developing their desire to experience that practice in spiritual destinations. These destinations become sacred landscapes and act as a 'faithscape,' which embodies not only their tangible geographical features and cultural establishments, but also intangible spiritual elements (Singh 2006).

Despite its increasing significance, spiritual tourism and its related phenomena remain a minor area of research in the field of tourism studies and social sciences. This paper focuses on the spiritual tourism phenomenon in Chiang Mai, Thailand, which is a popular spiritual tourism destination. Utilizing participant observation including informal conversations and 10 semi-structured interview data from two summers in 2016 and 2018, the research answers the question, "What is the role of faith in heritage tourism, particularly at sites with spiritual connections?" This exploratory research focuses on exploring the nature of Western tourists' faith in mindfulness and its role and impact on a spiritual tourism destination. Faith, in this context, refers to trust or confidence in something, rather than on empirical proof (Boa and Bowman 2006). Faith is often implied in religion, but it is also regarded as part of spiritual tourism. Whilst reporting preliminary findings, this paper also discusses the complexities of consumption of faith and commodification of spiritual sites. As spiritual tourism increases in Chiang Mai, the paper explores how local tourism authorities can utilize such tourism for tourism program development and as a heritage protection tool. The paper also discusses whether a 'Western yoga and 
mindfulness tourist bubble' that is separated from local culture and communities is emerging within the Old City of Chiang Mai.

\section{Spiritual Tourism}

Whilst pilgrimage is the oldest form of tourism, the concept has evolved over time. Self-described pilgrims make pilgrimages to memorials and other sites of loss, to their imagined homelands and heritage sites, to national parks, and to other places that hold particular personal importance (Di Giovine and Choe 2020; Ebron 1999; Ross-Bryant 2013). Graburn (1983, p. 13) argues that "ritual does not have to pertain to religion," and what is held sacred by society as one's fundamental structure of beliefs about the world should matter more to people. Many pilgrimage sites also have become secularized through modern tourism (Di Giovine and Picard 2015), with increased visitation to pilgrimage sites such as Camino de Santiago by spiritual tourists (Scriven 2014; Timothy and Olsen 2006).

Whilst traditional definitions of spirituality have also become fragmented as they become linked to secular overtones (Sharpley 2009; Willson 2016), spirituality is "semantically" located "both within and beyond" religion as it has the same inward direction, but it also strives to distance itself from religion (Stausberg 2014, p. 355). This desire to "distance oneself from traditional religiosity among modern spiritual pilgrims is apparent" in spiritual travel (Cheer et al. 2017, p. 253). With the recent growth and interest in spiritual travel, there has been a discursive shift from 'religious' to 'spiritual' (Kujawa 2012), situating spiritual tourism within the broader discourse of wellness and health. Fedele (2012) refers to spiritual tourists as the 'new pilgrims,' which she describes as travelers who visit traditional religious sites for reasons unlike those of traditional religious pilgrims. Such pilgrims seek happiness and well-being through spiritual experiences or healing methods based on their freely chosen quest instead of any religious obligation (Griffin and Raj 2017). Motives of spiritual tourists can include the "desire for new experiences, the wish to learn new way of thinking or being, and to think about their lives with the hope of gaining some new insights" (Norman and Pokorny 2017, p. 203). For example, tourists may walk the Camino de Santiago de Compostela without any religious obligation, but with "the hope of reaching some sort of resolution in their minds" (Norman and Pokorny 2017, p. 203). Frey (1998) wrote that people walk the Camino de Santiago de Compostela to find a link to the past and a way to connect meaningfully with themselves, others, and the land; they walk to accept and love themselves more and open themselves up to new ideas and patterns. Frey also went on to state that these people take a much-needed break from the rat race, and are attracted to the adventure, living with less, and relaxing for a while.

Spiritual tourism can be defined as a reflexive well-being intervention driven by the sense that some aspects of everyday life need improving, and oriented towards the space of nonwork from home where such problems can be given full attention (Norman and Pokorny 2017). It can be characterized by "a self-conscious project of spiritual betterment" (Norman 2011, p. 20). 'Spiritual tourists' may escape their everyday routine to distant spiritual spaces to work on their problems, or become a better person, whilst simultaneously leading to self- and personal transformation. According to Haq and Jackson (2009, p. 145), a spiritual tourist is "someone who visits a specific place out of his/her usual environment, with the intention of spiritual meaning and/or growth, without overt religious compulsion," which could be nonreligious, sacred, or experiential in nature. These tourists seek to understand their own sense of meaning, purpose, and identity, while recognizing that the spiritual activities are beneficial for their health and well-being (Cusack 2013; Duntley 2014; Eddy 2012; Howard 2012; Jepson 2015). They may visit religious heritage sites for their own spiritual pursuits.

Two of the most rapidly increasing forms of spiritual tourism are mindfulness and yoga tourism. Yoga tourism "focuses on the union of body, mind and spirit" (Smith and Kelly 2006, p. 17), and yoga tourists visit destinations that enable the attainment of physical, psychological, and well-being transformations (Bowers and Cheer 2017). Mindfulness tourism offers, through intensive training, deep insight, and removal from the everyday followed by return (Norman and Pokorny 2017). Mindfulness tourism often functions as "a self-administered well-being intervention" (Norman and Pokorny 2017, 
p. 201). Yoga and mindfulness tourism are seen as more 'authentic' amongst people and places in Asia (Bowers and Cheer 2017), with the number of mindfulness and yoga tourism destinations in Southeast Asia increasing in scope and scale due to the region's significant religious (e.g., Buddhism, Hinduism) heritage and traditions.

\section{Mindfulness Tourism to Southeast Asia}

Mindfulness, in particular, is a popular practice for Western travelers to pursue in Southeast Asia, given its history in Buddhist traditions (Hanh 1976) as a healing philosophy (Chen et al. 2017; Kabat-Zinn 2002) rather than a religious practice (Kabat-Zinn 1994). Mindfulness is often considered as awareness and a means of liberating the mind-from impermanence, suffering, and the nonexistence of self (Layman 1978). Numerous studies have suggested that mindfulness is related to increasing psychological health, and connected with "an integration of a harmonious integration of an individual's self with other individuals, autonomy, creativity, and a unifying philosophy of life" (Vegors 1999, p. 19). Due to these positive empirical findings, combined with tourist imaginaries, tourists have been drawn to religious sites in Southeast Asia.

Southeast Asia, therefore, is becoming an increasingly popular site for Westerners wishing to embark on mindfulness tourism (Laing and Weiler 2008). Tourists seek to explore "the possibility of better understanding what kinds of transformational possibilities are being experienced through 'doing' Eastern movement forms over extended periods of time"' (Brown and Leledaki 2010, p. 144). Yet, why would people need to travel to Southeast Asia for their mindfulness practices instead of doing it in their home countries? Di Giovine and Choe (2020) explain that "these places are often geographically separated from urban centers in which daily life takes its course" (p. 4), and "it is travel out of the profane world into that of the sacred" (Di Giovine and Choe 2020, p. 2). These sites are set apart from the profane and everyday world, and hold special importance to visitors since they promise some sort of personal and social transformation (Ferguson 2010).

Western spiritual tourists might also think of Southeast Asia as mysterious, wise, and spiritual, and they seek problem resolution by 'doing' their philosophy and traditional rituals, learned easily from mass media such as Hollywood movies (Beaman and Sonia 2016) like The Darjeeling Limited (2007) and Dr. Strange (2016) and YouTube videos. Bramham (2000, p. 301) notes that "myth, fantasy and imaginations are essential and integral elements in the social construction of all tourist sites." Whilst Strauss (2006) states that imaginaries are "implicit schemas of interpretations, rather than explicit ideologies" (p. 329), Salazar (2012, p. 864) conceptualizes those imaginaries as "socially transmitted representational assemblages that interact with people's personal imaginings and that are used meaning-making and world-shaping devices." Salazar (2012, p. 865) further explains this under the concept of tourism imaginaries, "seductive images and discourses about peoples and places are so predominant that without them there probably would be little tourism if any at all," which may explain why these spiritual tourists travel to exotic locations instead of practicing mindfulness at local mindfulness centers in their countries of residence.

Tourism authorities in Southeast Asia utilize and sometimes exploit these imaginaries for tourism promotion strategies. For example, Cohen (1989) discussed constructed representations of ethnic hill tribes by local small-scale, predominantly Thai-owned, trekking tour operators and their attempts to appeal to the 'quest for authenticity' they perceived amongst Western tourists. This awareness of a perceived Western quest for 'authenticity of experiences' has pervaded the machinations of the Thai tourist industry at all levels (Cohen 1989; Palmer 1994, 1998). In 1995, the Tourism Authority of Thailand launched a new promotional video 'Fields of Jade,' narrating 'a land that desires nothing, not changed in a world of change' and 'lost villages, lost years, spirits people never forget' (Palmer 1998). The new age ambience of the production plays on this purportedly 'authentic' spirituality, supplementing it with crude sexual imagery (Palmer 1998). The ironical consequence of the countercultural reaction to modern mass tourism in northern Thailand became "increasingly popular with the middle-aged and 
moneyed 'adventure' traveler set who wish 'to get away from it all' whilst still enjoying the luxurious of multi-star hotels" (Palmer 1998, p. 69).

Thus, with the increasing faith in spiritual practices from Western tourists (Smith 2003), the Southeast Asian region has gained economic benefits from spiritual tourism. Spiritual tourism has become an important economic sector with tourists contributing significantly to local and national economies through retreat centers, accommodation businesses, transportation, retail purchases and other spiritual activities (Tilson 2005). Many governments, national tourism authorities, destination management organizations, and local communities in India and Thailand, for example, recognize the economic benefits and are developing more tourism programs that have a differentiation strategy linked to spirituality and wellness. In India, towns close to the Tirupati temple in Andhra Pradesh, South India, depend on spiritual tourism (Tilson 2005), and it has proved resilient to the pressures of global recession (Selja 2010). The increasing numbers of tourists to the site and other temples have benefitted transportation, hotel, and restaurant businesses. It has also revitalized local arts, including stone and wood sculptures and jewelry (Tilson 2005). However, tourists have reported some challenges in visiting, due to issues of connectivity, infrastructure, sanitation, beggars, hygiene, lack of travel information, language barriers, poor services, and prevention of crime against women (Jauhari 2010).

In contrast, tourists visiting Thailand for their spiritual journeys find better infrastructure, transport systems, service quality, and perceived cleanliness, etc. (Choe and O' Regan 2015). As Thailand has long been associated with Buddhist culture, spiritual tourism has become a meaningful addition to the product offerings within Thailand's tourism industry (Schedneck 2017b). Thai tourism authorities are intent on changing their destination image from 'party and sex tourism' to something more positive and sophisticated. Thus, the Thai government and tourism authorities have invested in spiritual tourism. Chiang Mai, Thailand, in particular has been one of the successful examples in Southeast Asia, where marketing of spiritual tourism has succeeded (Choe and $O^{\prime}$ Regan 2015).

With a population of nearly two hundred thousand people, Chiang Mai is the second largest city in Thailand and the capital of northern Thailand. Known as 'a city of a hundred temples' (Schedneck 2017b), Chiang Mai's Old City, where Buddhist temples are concentrated, together with the nearby sacred temple of the Doi Suthep, was added to the list of Tentative UNESCO (The United Nations Educational, Scientific and Cultural Organization) World Heritage Sites in 2015 (UNESCO 2015). Chiang Mai is also home to Lanna Buddhism, a variant of Theravada Buddhism, evolved between the 13th and 16th centuries in northern Thailand. As Chiang Mai becomes a top tourist destination and cultural heritage center, visiting Buddhist sites has become a principal tourist activity (Schedneck 2017b). The Tourism Authority of Thailand emphasizes Chiang Mai's authentic ancient Buddhist temple sites (Schedneck 2017b) and "its distinctive culture and history as the former capital of the Lanna Kingdom stretching over 700 years" (Porananond and Robinson 2008, p. 312). Among several significant Buddhist sites, the Doi Suthep, situated in Suthep Mountain in Chiang Mai, has become one of the main destinations for the tourists visiting northern Thailand, with 160,000 visitors per month (Evrard and Leepreecha 2009). Many tour companies in Chiang Mai provide packaged programs for spiritual journeys. Chiang Mai also offers various spiritual activities (mainly run in English) such as long-term retreats in mountains, one/two-day mindfulness sessions, and yoga studios in convenient city locations besides mountains. Tourists can easily experience different kinds of spiritual practices depending on their previous knowledge and level or interest. The religious sites and tangible heritage, location, connectivity, people, convenience, and perceived cleanliness and the imagination (imaginary) of Chiang Mai are reasons it attracts international 'spiritual' tourists (Choe and O' Regan 2015; Schedneck 2017b). 


\section{Research in Chiang Mai, Thailand}

${ }^{1}$ I conducted participant observation including informal conversations and formal interviews during two summers in Chiang Mai in 2016 and 2018, to explore the nature of the spiritual tourism phenomenon. In the first two weeks, I attended various mindfulness and meditation sessions at multiple sites in order to meet and talk to people, so as to understand the nature of the phenomenon. I talked to tourists, travelers, expatriates, local academics, and Buddhist monks. I stayed and explored Buddhist temples and mindfulness centers in and nearby the Old City, where both heritage sites and spiritual tourist places are concentrated.

Besides talking to multiple people informally every day, I conducted 10 formal interviews and also interviewed two local monks at a Buddhist temple. The rest of the informants were interviewed at their preferred café in Chiang Mai, some in the Old City and the others outside the Old City. All of the informants were from Western developed countries including the USA (8), New Zealand (1), and Australia (1).

I chose two popular mindfulness and yoga sites and attended sessions every day. The first one was a commercial yoga/mindfulness studio in the Old City. It held various yoga, dance meditation, mindfulness workshops and art meditation programs taught by Western teachers. All yoga classes charge fees, but some weekly mindfulness workshops were free, and ask only for a donation. Mindfulness workshops were run by different teachers (all Americans) every week. We would sit and do walking meditation for $40 \mathrm{~min}$. Then, we would sit around in a circle and chat about our practice and what we are working on/through mindfulness and how we apply mindfulness in our everyday life. There was also a mindfulness group led by an American man who taught English to the monks at a Buddhist temple/Buddhist college, and he sometimes invited his students who were monks to the mindfulness workshops. They had an evening mindfulness group led by American expatriates who live in Chiang Mai. Interestingly, the group was following the teaching of the internationally renowned Vietnamese monk, Thích Nhất Hạnh, rather than Thai Buddhist teachers. As Thích Nhất Hạnh's teaching and his meditation practices have been very popular in the United States and Western Europe, it made sense. The visiting participants did not necessarily seem concerned about 'which Buddhism' they followed. In fact, of all of the people whom I spoke to, none would identify themselves as Buddhist, but 'kind of Buddhist,' 'just following Buddhist teaching' or 'I just like meditation.' So, being a Buddhist or not Buddhist did not seem an issue for them.

The other site I visited daily for my research was a Buddhist temple with a Buddhist college (for monks) just outside the Old City. The temple offers free weekly one-day meditation retreats and daily free 'monk chat' programs. They also run a weekly two-day meditation retreat in a mountain branch location, which charges about 200 Thai Baht (USD 7.00). Tourists would try the one-day retreat first, and if they were confident or more interested in a longer meditation retreat, they could then join the two-day one. When I spoke to two local monks who run a monk chat program, they mentioned that they started running the monk chat program around 2002. They were often approached by Western travelers whilst they were doing their work in temple gardens. Travelers would ask, "Monk, what is Buddhism?"; "What is mindfulness?"; "How's a monastic life like?", etc. As the monks were approached often with the same questions, they decided to offer monk chat hours, so that they could concentrate on their own work and separate out meeting time for travelers and tourists.

The 'monk chat' programs focus on teaching tourists about monastic life and meditation (Schedneck 2017a) and are 'open door.' Anyone can drop by a temple and chat to monks. The free programs are offered daily at several temples in the Old City and provide unique 'experiential' value for tourists and the opportunity for monks to practice English. These programs have been popular among tourists who seek to understand Buddhism and learn about spiritual practices linked to Buddhism. The variety of the Buddhist experience programs are particularly developed and varied, compared to

1 "I" refers to the first author. 
other spiritual destinations in Southeast Asia such as Luang Prabang (Laos), Bagan (Myanmar), Ubud (Bali, Indonesia), and Angkor Wat (Cambodia).

I interviewed a monk called AJ who ran this program. While I initially assumed he was local, I learned that he was originally from Bangladesh. As an orphan, he grew up in a temple in Bangladesh, moved to India to study Buddhism, and later moved to Chiang Mai, Thailand, for more general education. He said he loved studying many different subjects besides Buddhism, including English, and that is why he decided to stay in Chiang Mai. He told me that monks at the Chiang Mai Buddhist center were very international including other monks from Bangladesh, Vietnam, China, and India. According to him, both tourists and Buddhist monks are attracted to Chiang Mai for educational opportunities. AJ was very enthusiastic about my research, and he even encouraged both tourists and monks to talk to me and help my research during his meditation lesson sessions. Compared to the commercial yoga/mindfulness studio, people at the temple were beginners and/or short-stay tourists from Western countries including the UK, Spain, and Australia. During the time period that I was attending meditation sessions and workshops at the two sites, I had not seen any non-Western participants.

\section{Preliminary Research Outcomes}

Most of the Western tourists whom I interacted with in Chiang Mai initially experienced retreats or mindfulness centers back in their home countries. They found that traveling to religious heritage sites in Asia helped their mindfulness practice. Some visited Chiang Mai as an escape from their lives, with self-transformation achieved through being surrounded by many Buddhist temples, monks, mountains, mindfulness and yoga centers. Other spiritual tourists confirmed their faith through a spiritual recharge or fulfilment through mindfulness practices in the 'right' location and atmosphere. All informants participated in long-term mindfulness retreats either in their home country or in other locations in Asia, and they felt being on lengthy retreats as important for their practice.

Most of the informants I met had decided to live in Chiang Mai full time. All informants whom I met for informal conversations and formal interviews from the two meditation sites were from the USA, the UK, Australia, New Zealand, Spain, and Germany. This might be similar in other popular perceived 'spiritual' destinations in other parts of South and Southeast Asia. Many of these 'permanent' tourists (Sharpley and Sundaram 2005) were in their 60s, and had travelled extensively in Asia, and had lived in other parts of Asia. Most of them had been to India, Nepal, Laos, and Japan for spiritual exploration and practice. Jack from California travelled extensively in Asia and lived in India, Myanmar, and Laos. He decided to live in Chiang Mai as things are more "easy going" (compared to Laos and Myanmar), and there are plenty of mindfulness retreats. He started his commitment to dedicated mindfulness practice back in California after his mother's death, and used the practice as a coping strategy. William from Colorado also has travelled all over Asia and went to long-term mindfulness retreats in Nepal, India, and Japan. He prefers to live in Chiang Mai as he can easily go to mountains and sit there for his own mindfulness practice, and had access to lots of spaces for mindfulness and hanging out with his 'spiritual friends.' William had been married to a Thai woman and had gone through a tough divorce. He then went through two month-long mindfulness retreats in a mountain location, run by his American friends, and he felt it helped him enormously. He said, "it reset everything!" William said he just wants to know the 'truth' through his mindfulness practices, as he always adds interpretations and thoughts to what happens in life, which creates worries and conflict. Jack and William both taught English to Buddhist monks at a local Buddhist temple/college. They both strongly believed that, without mindfulness practices, their day (and life) would not go well. They felt it was easy to meditate anytime and anywhere in Chiang Mai, given its unique atmosphere, history, and heritage. William also mentioned that he likes to live outside the United States as he feels free from 'judgement,' and appreciates the local people's wisdom.

I also met Sarah (in her mid-20s) who was working as a receptionist at a yoga/mindfulness center. Originally from New Zealand, she had stayed in Chiang Mai for a few months to get training as a 
dance meditation teacher. She left home in New Zealand as she felt there was too much competition and judgment back home, whereas she does not feel that way in Chiang Mai. In Chiang Mai, she worked at a yoga center whilst taking their classes for free, and she was staying at a nearby yoga center with accommodation for free. While she lives in a yoga center and works at a yoga studio, she really likes living in the 'bubble,' which she calls an 'oasis.' She noted that she needed this kind of space, where she could, unlike back home, belong to a community very quickly. She practices mindfulness 24/7, and she has been enjoying learning about dance meditation in Chiang Mai. Interestingly, she said she finally "feels at home" in Chiang Mai and enjoys being around open-minded people. She planned to become a dance meditation teacher in Australia and she was crowd-funding from her friends, so she can buy air tickets to Australia. She mentioned how the dance meditation really helped her emotion management and helped her develop a calm, loving, kind, and compassionate mind. She emphasized that mindfulness practices have helped her cope with negative emotions in a constructive way. She chose to become a dance meditation teacher, integrating it fully into the fabric of her life.

I met with Peter at a mindfulness group workshop in the Old City when he visited to deliver his workshop. He was an American mindfulness teacher at an American-based retreat center in Chiang Rai, and he firstly got into mindfulness through psychiatric advice during his youth, and since then, it has been working well for him. He became a mindfulness teacher, helping young adults with drug problems. He said mindfulness makes him smart, rather than just generous and kind. He emphasized that, for a long and sustained practice, he has to be in an environment, like Chiang Mai with less distraction, where it is easier to practice. He goes to a long retreat for a month (at least 10 days) once or twice a year. He has participated in long retreats in northern California and several places in Thailand. He stressed:

"People say, people come here for authentic Buddhism, but what does that mean? I don't know. Buddhism is everywhere. I am an American, and actually there is lots of Buddhism in America too ... Maybe here is more authentic Thai, northern Buddhism. If you go to south, it's a little bit different too. Maybe there are more cultural implications here (than the U.S.). More cultural. I think people come here for that reason-Cultural; and it's generally pleasant and inexpensive".

Peter said that he wanted his teaching to be practical and pragmatic, rather than mystical. He wanted to teach others how to do mindfulness. All informants seemed to have 'faith' that mindfulness practice could resolve their problems and help them to constructively work on negative life events (e.g., divorces, family members' deaths, anxiety, depression, and drug abuse). Several informants also noted that their goal was to integrate the mindfulness method into the fabric of their everyday life. These spiritual tourists seem to treat Chiang Mai as an escape from being constantly judged by the societies they left. Many informants decided to move to Chiang Mai after visiting as spiritual tourists, and hope to seek the spiritual life full time and practice their spiritual routine full time. Norman (2011) noted, "it thereby transcends, for tourists, the notion that spirituality, and by extension religion, is a matter only of faith" (p. 35). He went on to write that "simple belief is not sufficient for spiritual tourists in Rishikesh. Only experience is valid, thus by engaging with an intensive period of spiritual experience they are elevating their own spiritual practice to a more cognitively defensible position" (p. 35). Thus, the tourists focus more on 'doing,' experiences and practices of their faith, rather than just 'being.'

\section{Tourists' Faith and Consumption}

In many Western countries, global capitalism has created a feeling of existential angst or alienation amongst a growing number of people, with long working hours and the fragmentation of communities and traditions exacerbating feelings of isolation, depression, and stress (Smith 2003). With increasing feelings of isolation, depression, and stress, faith in Eastern spiritual activities has been attractive to 
those seeking to solve their problems. Combined with the consumption of imaginaries (Salazar and Nelson 2014) of Buddhist heritage sites and people in Southeast Asia, Western demand for spiritual tourism has accelerated. Western tourists' faith in mindfulness practices in Chiang Mai has been positive to the local economy and tourism development. For some, Chiang Mai can be seen as a successful benchmark case study for spiritual tourism destinations from a destination management organization's perspective. From city branding to economic development through spiritual-niche tourism programs and products, the Thai government and tourism authorities have been successful in supporting and strategically marketing Chiang Mai as a spiritual tourism destination, benefiting the rural local economy and contributing to new livelihoods and local pride.

However, I observed that there were numerous yoga/mindfulness centers in Chiang Mai that are run and managed by Western investors and teachers, to meet Western tourists' demand. I hardly ever saw any local people at the yoga and mindfulness centers and saw only Western people teaching and practicing those activities. In fact, some Western tourists might visit these yoga and mindfulness centers, tour Buddhist temples, talk to some local monks through 'monk chat' programs, and limit their experiences to the Old City of Chiang Mai. The reality, however, is that Chiang Mai is the second biggest city in Thailand, and has an urban city center with lots of modern leisure facilities. Some informants choose not to see or experience life outside the 'oasis.' Given the 'Enclavic' (Edensor 2008) nature of their experiences, Chiang Mai's spiritual tourism agenda has been criticized by scholars for its commercialization of cultural heritage. Scholars have argued that their ancient Buddhist temples, Buddhism, and even monks have become overly commoditized to attract and satisfy tourist imaginaries, and deliver only economic benefits (Schedneck 2014, 2017b). The Tourism Authority of Thailand marketing campaigns, travel advertisement websites, and well-being and yoga magazines project Chiang Mai as a peaceful spiritual destination, with photos of solitary monks walking in lush temples, which might not represent the reality of the local people's lives (Schedneck 2014, 2017b). In a way, Chiang Mai became "subjected to a discourse of culture premised on the fetishism of appearance" (Morris 2000, p. 237). Western tourists look for "exoticism and authenticity in the Others' past" (Evrard and Leepreecha 2009, p. 307). The ability to experience Buddhist temple life, with its ceremonies and robed monks while traveling in Chiang Mai, can be seen as "a commodity consumed by interested English-speaking travelers from the Global North" (Schedneck 2017a, p. 58).

Porananond (2015), a local Chiang Mai scholar, notes that sand pagodas-miniature structures made out of sand by the faithful to earn merit-have transformed into a tourist commodity. This transformation was led by local religious groups and monks, and it was "an ironic situation given the decline in the importance of its original religious significance" (Porananond 2015, p. 170). Commercialization of Buddhist sites and Buddhism is also seen across Asia. Shinde (2010) notes that Western spiritual package tourism programs in India offer luxury tour packages and comforts. As a higher degree of consumerism and hedonistic behavior, in the search for 'instant nirvana' (Shinde 2010), formal agencies such as institutions (ashrams) emerge to offer charismatic gurus and specialized tour operators to cater to upmarket clientele by selling products such as yoga journeys and spiritual healing. The proliferation of hundreds of self-proclaimed and charismatic gurus illustrates the entrepreneurial role they play in driving this market (Reader 2007; Rinehart and Rinehart 2004), and diminishing the original meaning and value of their religions and spiritual practices.

The branding and the commercialization of a destination for spiritual and peaceful places also can be used as national political propaganda. Philp and Mercer (1999) stress that commodifying Buddhism for tourism consumption, and the packaging of heritage icons as attractions, can be the means by which political legitimacy is achieved. Myanmar's marketing strategies have focused on "a picturesque and idyllic landscape, imbued with spirituality as a consequence of its Buddhist traditions, and inhabited by an unchanging people whose traditional culture has been presented" (Philp and Mercer 1999, p. 50). While the image of Myanmar is presented by its government as a united and peaceful country, harsh realities underlie such representations, given the elimination of minority racial, cultural, and religious differences (Philp and Mercer 1999). Similarly, Sri Lanka has been promoting the 
emerging and lucrative tourism products of spiritual retreats, branding the destination as a peaceful country, but eliminating the reality of religious and political conflicts (Johansson 2018). Such historical sites are increasingly sanitized landscapes, which have been reinvented for the tourist gaze as well as the achievement of nationalist ambitions. It is problematic that local cultures, their places, and people became "objects of desire and marketing for tourists as part of a process of control and pacification of social relations" (Evrard and Leepreecha 2009, p. 304). In this aspect, Western tourists' faith in spiritual tourism to South and Southeast Asia could be seen as an escalator for the commodification of Buddhism and other spiritual practices such as mindfulness and yoga (Christopher et al. 2009; Geary 2008; McCartney 2019).

However, the relationship between religious heritage and commodification is rather complex and delicate, as they are intertwined and reinforce each other (Schedneck 2017b). The process of cultural commodification may serve as an active way of motivating, transmitting, and preserving the value of the intangible heritage through creating a market for commercial products (Ratchaneekorn 2015). Cohen (2016) argues that the local and regional religious festivals that attract tourists can help maintain meaning and value of its own culture and tradition instead of disappearing or being forgotten by the young generation. Through the heritage of northern Thailand being identified, labelled, promoted, and preserved, "commodification of the tangible products and intangible experiences can contribute to the interest and sustaining of cultural practices" (Schedneck 2017b, p. 117). Thus, this transmission of heritage can be balanced with the negative effects of tourism (Schedneck 2017b). Using Lanna Buddhism as an example, Schedneck (2017b) goes on to state that whilst Lanna Buddhism and culture is performed, displayed, engaged with, and commodified as a unique tourism attraction of the region, commodification from Lanna Buddhism has also helped promote and preserve a wide range of artistic skills for the future. She emphasizes that Lanna Buddhism in Chiang Mai is not changed or altered with unique experiences and products preserved with the help of tourism.

The culture of artistry and performance of Lanna Buddhism is still used for worship, decoration, and pride. Tourism encourages and enhances elements of Lanna Buddhism, but does not lead to any radical cultural shifts. Rituals and art are not totally transformed with their original purpose becoming something entirely different. The commodification and promotion of Lanna Buddhism do not reinvent the tradition, but demonstrates the influence and demands of tourism development while providing a way for interest in the cultural traditions of the Lanna region to continue. (Schedneck 2017b, p. 117)

It is important to pay attention to "how the aesthetic importance of authenticity and the meaningful values attributed to things deemed religions rely on the logic and practical objectives of marketplace capitalism" (Bremer 2014, p. 377). In the Lanna Buddhism case, "commodity value is implicated in religious value as well as the reverse - how religious value can translate into commodity value" (Schedneck 2017b, p. 103).

\section{Discussion and Conclusions}

Spiritual tourists travel to destinations for problem-solving, well-being intervention, spiritual fulfilment, and transformative potential—based on their individual faith (Norman 2011; Sharpley and Sundaram 2005; Smith 2003). This paper explored why Western tourists without religious affiliation, but with individual faith, travel to a destination with religious heritage sites, to engage in mindfulness practices. The preliminary findings indicate that the informants all experienced spiritual practices such as mindfulness back home, and chose to visit Buddhist heritage sites in Southeast Asia, such as Chiang Mai.

None of our informants identified themselves as Buddhist, though they seriously engage in mindfulness practices. Indeed, in a postmodern era, spiritual travel to imagined homelands and heritage sites, and to other places that hold particular importance to the individual (Di Giovine and Choe 2019), has become more secular and nonreligious (Dubisch and Winkelman 2005; Gammon 
2004; Margry 2008; Morinis 1992; Reader and Walter 1993). Their primary purposes for engaging in mindfulness were spiritual fulfilment, battery recharge, self-reassessment and personal reflection. More specifically, they informants were working on difficulties in their lives such as divorces, break-ups, deaths in the family, drug abuse/recovery and other anxiety-related issues. However, this represents saturated data from our informants, with spiritual tourists also visiting Southeast Asia to learn about the religion and culture without having negative life events driving them. Our informants were either well aware of, or experienced the benefits of, spiritual practices in dealing with life events and issues, and sought to continue and engage at a deeper level, and eventually live in their chosen practice full time.

Our informants all had a strong faith in the mindfulness practice for solving problems and sought to embed those techniques full time by way of lifestyle migration. Chiang Mai was chosen because they appreciated Chiang Mai's spiritual atmosphere, numerous significant and Buddhist temples, and opportunities to talk to monks, whilst enjoying mindfulness and yoga centers that offer programs in English. Whilst seeking to achieve better well-being for themselves, those who moved to Chiang Mai full time sought transformative potential in their lives. As Di Giovine and Choe (2019) note, these sites are set apart from the profane and everyday world, and hold special importance to visitors, as they often promise some sort of personal or social transformation.

Because of their faith and imaginary of Chiang Mai, 'Western' mindfulness traditions have attained hyper-meaningfulness (Di Giovine 2013), allowing Chiang Mai to successfully transform into an internationally recognized spiritual tourism destination. The spiritual tourism phenomenon has led to more tourism products such as mindfulness retreat centers, yoga studios, spiritual festivals and other programs at Buddhist temples, which has contributed to the local economy and livelihoods. However, some concerns have arisen from the touristification of Buddhist temples, Buddhism, monks, and the local heritage and culture in Chiang Mai. The increasing number of yoga/mindfulness studios in Chiang Mai run and managed by Western investors and teachers, to meet Western tourists' demand, have created a tourist bubble, and led to economic leakage. These businesses are often separated from local culture and communities, and degrade the original meaning and value of the practices they teach and purport to support. Tourism development solely focusing on the economic benefit instead of understating wider sociocultural issues can threaten both tangible and intangible cultural heritage. As Di Giovine and Garcia-Fuentes (2016) state, a highly valued heritage site may be seen as sacred, but it is always threatened by secularization through the phenomenon of modern tourism (see also Di Giovine and Picard 2015). There is an opportunity and hope, however, that commodification and tourists' interest in Chiang Mai heritage and culture can help preserve culture and keep traditions alive, so that they are retained for religious and spiritual practice by local people and future generations (Cohen 2016).

While Western tourists' faith in mindfulness practices, places, and people might be based on their imaginaries, and mass media coverage, their faith is then established and grown by their individual travel experiences. The interesting aspect around this phenomenon is that the tourists travel and seek spiritual fulfilment in places where there are existing and accessible religious heritages sites. Spiritual tourists visit Chiang Mai to participate in mindfulness activities amongst ancient Buddhist temples, which coexist as major religious heritage markers. Even though they are not interested in actually being religious, they like to engage in spiritual practices surrounded by Buddhist temples, so as to draw from a more serene, tranquil, and serious context. Future research can explore more nuanced interrelationships between Western tourists' faith and Eastern spiritual heritage in different destinations, and the tension and conflict around the Western yoga and mindfulness bubble that is separated from local culture and communities.

Author Contributions: J.C., the first author, conducted the field-work including formal interviews, informal conversations and participant observation on spiritual tourism and its related phenomena in Chiang Mai, Thailand and wrote the paper. M.O'R., the second author, critically analyzed the draft, edited drafts and recommended key references. All authors have read and agreed to the published version of the manuscript. 
Funding: This research was supported by Faculty of Management, Bournemouth University, U.K.

Conflicts of Interest: The authors declare no conflicts of interest.

\section{References}

Beaman, Lori G., and Sikka Sonia, eds. 2016. Constructions of Self and Other in Yoga, Travel, and Tourism: A Journey to Elsewhere. Berlin/Heidelberg: Springer.

Boa, Kenneth, and Robert M. Bowman Jr. 2006. Faith Has Its Reasons: Integrative Approaches to Defending the Christian Faith. Westmont: InterVarsity Press.

Bowers, Hana, and Joseph M. Cheer. 2017. Yoga tourism: Commodification and Western embracement of eastern spiritual practice. Tourism Management Perspectives 24: 208-16. [CrossRef]

Bramham, P. 2000. Review of Rojek and Urry's Touring cultures, transformations of travel and theory. Leisure Studies 19: 301-3.

Bremer, Thomas S. 2014. A touristic angle of vision: Tourist studies as a methodological approach for the study of religions. Religion Compass 8: 371-79. [CrossRef]

Brenhouse, Hillary. 2010. Bali's Travel Boom: Easy, Pray, Love Tourism. Time Magazine, July 22. Available online: http://www.time.com/time/printout/0,8816,2011931,00.html (accessed on 2 October 2019).

Brown, David, and Aspasia Leledaki. 2010. Eastern movement forms as body-self transforming cultural practices in the West: Towards a sociological perspective. Cultural Sociology 4: 123-54. [CrossRef]

Cheer, Joseph M., Yaniv Belhassen, and Joanna Kujawa. 2017. The search for spirituality in tourism: Toward a conceptual framework for spiritual tourism. Tourism Management Perspectives 24: 252-56. [CrossRef]

Chen, Lynn I-Ling, Scott Norman, and Pierre Benckendorff. 2017. Mindful tourist experiences: A Buddhist perspective. Annals of Tourism Research 64: 1-12. [CrossRef]

Choe, Jaeyeon, and Michael O' Regan. 2015. Case Study 2: Religious Tourism Experiences in East Asia. In Religious Tourism and Pilgrimage Management: An International Perspective, 2nd ed. Edited by R. Raj and K. Griffin. Oxfordshire: CAB International.

Christopher, Michael S., Varinthorn Christopher, and Sukjai Charoensuk. 2009. Assessing "western" mindfulness among Thai Theravāda Buddhist monks. Mental Health, Religion and Culture 12: 303-14. [CrossRef]

Cohen, Erik. 1979. A phenomenology of tourist experiences. Sociology 13: 179-201. [CrossRef]

Cohen, Erik. 1989. Primitive and remote: Hill tribe trekking in Thailand. Annals of Tourism Research 16: 30-61. [CrossRef]

Cohen, Paul T. 2016. Introduction: Charismatic Monks of Lanna Buddhism. In Charismatic Monks of Lanna Buddhism. Edited by Paul Cohen. Copenhagen: NIAS Press.

Cusack, Carole M. 2013. History, authenticity, and tourism: Encountering the medieval while walking Saint Cuthber's way. In Journeys and Destinations: Studies in Travel, Identity, and Meaning. Edited by Alex Norman. Newcastle-upon-Tyne: Cambridge Scholars Press, p. 1022.

Di Giovine, Michael A. 2013. Apologia Pro turismo: Breaking inter- and intra-disciplinary boundaries in the study of tourism and pilgrimage. The Journal of Tourism Challenges and Trends 6: 63-94.

Di Giovine, Michael A., and Jaeyeon Choe. 2019. Geographies of Religion and Spirituality: Pilgrimage beyond the 'Officially' Sacred. Tourism Geographies: An International Journal of Tourism Space, Place and Environment 21: 361-83. [CrossRef]

Di Giovine, Michael A., and Jaeyeon Choe, eds. 2020. Pilgrimage beyond the Officially Sacred: Understanding the Geographies or Religion and Spirituality in Sacred Travel. New York: Routledge.

Di Giovine, Michael A., and Josep-Maria Garcia-Fuentes. 2016. Sites of pilgrimage, sites of heritage: An exploratory introduction. International Journal of Tourism Anthropology 5: 1-23.

Di Giovine, Michael A., and David Picard, eds. 2015. The Seductions of Pilgrimage: Sacred Journeys Afar and Astray in the Western Religious Tradition. Surrey: Ashgate.

Dubisch, Jill, and Michael Winkelman, eds. 2005. Pilgrimage and Healing. Tucson: University of Arizona Press.

Duntley, Madeline. 2014. Spiritual tourism and frontier esotericism at Mount Shasta, California. International Journal for the Study of New Religions 5: 123-50. [CrossRef]

Ebron, Paulla A. 1999. Tourists as pilgrims: Commercial refashioning of translatic relations. American Ethnologist 26: 910-32. [CrossRef] 
Eddy, Glenys. 2012. The Vipassana retreat experience: A consideration of the meditation retreat as a religious paradigm of travel. Literature $\mathcal{E}$ Aesthetics 22: 38-59.

Edensor, Tim. 2008. Tourists at the Taj: Performance and Meaning at a Symbolic Site. Abingdon: Routledge.

Evrard, Olivier, and Prasit Leepreecha. 2009. Monks, Monarchs and Mountain Folks. Critique of Anthropology 29: 300-23. [CrossRef]

Fedele, Anna. 2012. Looking for Mary Magdalene: Alternative Pilgrimage and Ritual Creativity at Catholic Shrines in France. Oxford: Oxford University Press.

Ferguson, Duncan S. 2010. Exploring the Spirituality of the World Religions: The Quest for Personal, Spiritual and Social Transformation. London: Bloomsbury Publishing.

Frey, Nancy Louise. 1998. Pilgrim Stories: On and off the Road to Santiago, Journeys along an Ancient Way in Modern Spain. Berkeley: University of California Press.

Gammon, Sean. 2004. Secular pilgrimage and sport tourism. In Sport Tourism: Interrelationships, Impacts and Issues. Edited by Brent W. Ritchie and Daryl Adair. Clevdon: Channel View, pp. 30-45.

Geary, David. 2008. Destination enlightenment: Branding Buddhism and spiritual tourism in Bodygaya, Bihar. Anthropolgoy Today 24: 11-14. [CrossRef]

Gilbert, Elizabeth. 2006. Eat Pray Love: One Woman's Search for Everything. London: Bloomsbury Publishing.

Graburn, Nelson H. H. 1983. The anthropology of tourism. Annals of Tourism Research 10: 9-34. [CrossRef]

Griffin, Kevin, and Razaq Raj. 2017. The Importance of Religious Tourism and Pilgrimage: Reflecting on definitions, motives and data. International Journal of Religious Tourism and Pilgrimage 5. [CrossRef]

Hanh, Thick Nhat. 1976. The Miracle of Mindfulness. Boston: Beacon Press.

Haq, Farooq, and John Jackson. 2009. Spiritual journey to Hajj: Australian and Pakistani experience and expectations. Journal of Management, Spirituality and Religion 6: 141-56. [CrossRef]

Howard, Christopher. 2012. Horizons of possibilities: The telos of contemporary Hymalayan travel. Literature $\mathcal{E}$ Aesthetes 22: 131-55.

Ireland, Brian, and Sharif Gemie. 2015. From Kerouac to the hippy trail: Some notes on the attraction of on the Road to British hippies. Studies in Travel Writing 19: 66-82. [CrossRef]

Jauhari, Vinnie. 2010. How can the visitor experience be enhanced for spiritual and cultural tourism in India? Worldwide Hospitality and Tourism Themes 2: 559-63. [CrossRef]

Jepson, Deborah. 2015. The lure of the countryside: The spiritual dimension of rural spaces of leisure. In Landscapes of Leisure. London: Palgrave Macmillan UK, pp. 202-19.

Johansson, Andreas. 2018. The 2018 Political Crisis and Muslim Politics in Sri Lanka. ISAS Insight. Available online: https://www.isas.nus.edu.sg/wp-content/uploads/2018/12/ISAS-Insights-No.-526-The-2018-politicalcrisis-and-Muslim-politics-in-Sri-Lanka.pdf (accessed on 20 January 2020).

Kabat-Zinn, Jon. 1994. Wherever You Go, There You Are: Mindfulness Meditation in Everyday Life. New York: Hyperion.

Kabat-Zinn, Jon. 2002. Meditation is about paying attention. Reflections: The SoL Journal 3: 68. [CrossRef]

Kabat-Zinn, Jon. 2015. Mindfulness. Mindfulness 6: 1481-83. [CrossRef]

Kerouac, Jack. 1957. On the Road. New York: Viking.

King, Victor T. 2017. Introduction to the Special Issue: Emerging tourisms and tourism studies in Southeast Asia. Asian Journal of Tourism Research 2: 1-32. [CrossRef]

Kujawa, Joanna. 2012. Jerusalem Diary: Searching for the Tomb and House of Jesus. Bloomington: Balboa Press.

Laing, Jennifer, and Betty Weiler. 2008. Mind, body and spirit: Health and wellness tourism in Asia. Health and Wellness Tourism in Asia 1. [CrossRef]

Landau, M. D. 2011. Out of Your Mind: How Mindfulness Soothes Hot Flashes and Quells; IBS, October. Available online: http://www.huffingtonpost.com/meryl-davids-landau/mindfulness-health-benefits-_b_1028639.html (accessed on 16 September 2014).

Layman, Emma McCloy. 1978. Buddhism in America. Chicago: Nelson-Hall.

MacCannell, Dean. 2013. The Tourist: A New Theory of the Leisure Class. Berkeley: University of California Press.

Marchant, Jo. 2011. How meditation might ward off the effects of ageing. The Guardian, April 23.

Margry, Peter Jan. 2008. Shrine and Pilgrimage in the Modern World: New Itineraries into the Sacred. Amsterdam: Amsterdam University Press.

McCartney, Patrick. 2019. Stretching into the shadows: Unlikely alliances, strategic syncretism, and de-post-colonizing yogaland's "yogatopia(s)". Asian Ethnology 78: 373-401.

Morinis, E. Alan. 1992. Sacred Journeys: The Anthropology of Pilgrimage. Westport: Greenwood. 
Morris, Rosalind C. 2000. In the Place of Origins: Modernity and Its Mediums in Northern Thailand. Duke: Duke University Press.

Norman, Alex. 2011. Spiritual Tourism: Travel and Religious Practice in Western Society. London: Bloomsbury Publishing.

Norman, Alex, and Jennifer J. Pokorny. 2017. Meditation retreats: Spiritual tourism well-being interventions. Tourism Management Perspectives 24: 201-7. [CrossRef]

O'Connor, Noelle, and Sangkyun Kim. 2014. Pictures and prose: Exploring the impact of literacy and film tourism. Journal of Tourism and Cultural Change 12: 1-17. [CrossRef]

Palmer, Catherine A. 1994. Tourism and colonialism: The experience of the Bahamas. Annals of tourism Research 21: 792-811. [CrossRef]

Palmer, Lisa. 1998. On or Off the Beaten Track? Tourist Trails in Thailand. UTS Review: Cultural Studies and New Writing 4: 67-91.

Philp, Janette, and David Mercer. 1999. Commodification of Buddhism in contemporary Burma. Annals of Tourism Research 26: 21-54. [CrossRef]

Porananond, Ploysri. 2015. Tourism and the transformation of ritual practice with sand pagodas in Chiang Mai, Northern Thailand. Tourism Review 70: 165-78. [CrossRef]

Porananond, Ploysri, and Mike Robinson. 2008. Modernity and the Evolution of a Festive Tourism Tradition: The Songkran Festival in Chiang Mai, Thailand. In Asian Tourism: Growth and Change. Edited by Cochrane Janet. Oxford: Elsevier, pp. 311-22.

Ratchaneekorn, Sae Wang. 2015. Spirit of the Loom: The Conservation and Commodification of Surin's Textile Cultural Heritage. International Journal of Intangible Heritage 10: 86-100.

Reader, Ian. 2007. Pilgrimage growth in the modern world: Meanings and implications. Religion 37: $210-29$. [CrossRef]

Reader, Ian, and Tony Walter. 1993. Pilgrimage and Popular Culture. London: Macmillan.

Reck, David R. 1985. Beatles Orientalis: Influences from Asia in a Popular Song Tradition. Asian Music 16: 83-149. [CrossRef]

Regan, S. 1967. The Thumbers. News of the World, July 2.

Rinehart, Robin, and Robert Rinehart, eds. 2004. Contemporary Hinduism: Ritual, Culture, and Practice. Santa Barbara: ABC-CLIO.

Ross-Bryant, Lynn. 2013. Pilgrimage to the National Parks: Religion and Nature in the United States. Abingdon: Routledge, vol. 1.

Said, Edwar W. 1978. Orientalism. London: Penguin.

Salazar, Noel B. 2012. Tourism imaginaries: A conceptual approach. Annals of Tourism Research 39: $863-882$. [CrossRef]

Salazar, Noel B., and Graburn Nelson. 2014. Tourism Imaginaries: Anthropological Approaches. Oxford: Berghahn.

Schedneck, Brooke. 2014. Meditation for Tourists in Thailand: Commodifying a universal and national symbol. Journal of Contemporary Religion 29: 439-456. [CrossRef]

Schedneck, Brooke. 2017a. Beyond the glittering golden Buddha statues: Difference and self-transformation through Buddhist volunteer tourism in Thailand. Journeys 18: 57-78. [CrossRef]

Schedneck, Brooke. 2017b. Presenting 'Lanna' Buddhism to domestic and international tourists in Chiang Mai. Asian Journal of Tourism Research 2: 102-21. [CrossRef]

Schocker, L. 2014. LOOK: What Meditation Can Do for Your Mind, Body and Spirit. May. Available online: http://www.huffingtonpost.com/2014/05/14/meditation-mind-body-spirit_n_5291361.htm (accessed on 16 September 2014).

Scriven, Richard. 2014. Geographies of pilgrimage: Meaningful moments and embodied mobilities. Geography Compass 8: 249-61. [CrossRef]

Selja, K. 2010. PIB Press Release; New Delhi: Ministry of Tourism, Government of India.

Sharpley, Richard. 2009. Tourism, religion and spirituality. In The SAGE Handbook of Tourism Studies. Edited by Tazim Jamal and Mike Robinson. Thousand Oaks: Sage Publications.

Sharpley, Richard, and Priya Sundaram. 2005. Tourism: A sacred journey? The case of ashram tourism, India. International Journal of Tourism Research 7: 161-71. [CrossRef]

Shinde, Kian A. 2010. Entrepreneurship and indigenous entrepreneurs in religious tourism in India. International Journal of Tourism Research 12: 523-35. 
Singh, Rana P. B. 2006. Pilgrimage in Hinduism: Historical Context and Modern Perspectives. In Tourism, Religion and Spiritual Journeys. Edited by Dallen J. Timothy and Daniel H. Olsen. London: Routledge.

Smith, Melanie. 2003. Holistic holidays: Tourism and the reconciliation of body, mind and spirit. Tourism Recreation Research 28: 103-8. [CrossRef]

Smith, Melanie, and Catherine Kelly. 2006. Wellness Tourism. Tourism Recreation Research 31: 1-4. [CrossRef]

Stausberg, Michael. 2014. Religion and spirituality in tourism. In The Wiley Blackwell Companion to Tourism. Edited by Alan A. Lew, Colin M. Hall and Allan M. Williams. Hoboken: Wiley, pp. 349-60.

Strauss, Claudia. 2006. The imaginary. Anthropological Theory 6: 322-44. [CrossRef]

Tilson, Donn James. 2005. Religious-Spiritual Tourism and Promotional Campaigning: A Church-State Partnership for St. James and Spain. Journal of Hospitality \& Leisure Marketing 12: 9-40. [CrossRef]

Timothy, Dallen, and Daniel Olsen, eds. 2006. Tourism, Religion and Spiritual Journeys. New York: Routledge.

UNESCO. 2015. Monuments, Sites, and Cultural Landscapes of Chiang Mai, Capital of Lanna [online]. Available online: http://whc.unesco.org/en/tentativelists/6003/ (accessed on 31 January 2017).

UNWTO. 2013. International Conference: Declarationon Spiritual Tourisfor Sustainable Development, Ninh Binh City, Vietnam, November 21-22, 2013. Madrid: UNWTO.

Vegors, Susan. 1999. Developing psychological health with transcendental meditation. Alternative Health Practitioner 5: 19-22. [CrossRef]

Willson, Gregory Brian. 2016. Conceptualising spiritual tourism: Cultural considerations and a comparison with religious tourism. Tourism, Culture $\mathcal{E}$ Communication 16: 161-68.

(C) 2020 by the authors. Licensee MDPI, Basel, Switzerland. This article is an open access article distributed under the terms and conditions of the Creative Commons Attribution (CC BY) license (http://creativecommons.org/licenses/by/4.0/). 